\title{
Rating of Results of Culture Budgets Spending
}

Tatiana M. Kovaleva ${ }^{1}$

\author{
Alla G. Glukhova² \\ Irina A. Boiko ${ }^{3}$ \\ ${ }^{1}$ Samara State University of Economics, Russia, 443090, Samara, Sovetskoi Armii Street,141 \\ 2 Samara State University of Economics, Russia, 443090, Samara, Sovetskoi Armii Street, 141 \\ ${ }^{3}$ Samara State University of Economics, Russia, 443090, Samara, Sovetskoi Armii Street,141 \\ Correspondence: Samara State University of Economics, Russia, 443090, Samara, Sovetskoi Armii Street,141, e-mail: fikr@bk.ru
}

Doi:10.5901/mjss.2015.v6n6s3p367

\section{Abstract}

The article views the problems of successful culture budgets spending. We demonstrate that the successfulness of culture budgets spending depends on the volume of public benefits which can be obtained in conditions of limited budget resources. Researching culture budget spending we made the rating of results according to financial, social, human resources and services quality indicators. The research suggests that the process of culture budgets spending can be optimized if it is based on the given principles.

Keywords: state expenses, expenses on cultural services, monitoring, efficiency, results rating.

\section{Introduction}

\subsection{The relevance of the problem}

Recently the Russian Federation has faced the process of reforming of state and municipal finance. The goal of this reforming if the increase of effectiveness and quality of public (state and municipal) finance. The reforming is performed in accordance with the tasks given by the President of the Russian Federation to the Federal Assembly of the Russian Federation and the programmes of structural reforms in the sphere of state and municipal finance management.

Modern problems of successful budgets spending and possible solutions of these problems are widely discussed in the economics literature. Study and systematization of works of leading scientists and specialists in the sphere of state finance revealed the necessity of more profound research of budgets spending effectiveness. Successful planning of budgets spending on culture is very important nowadays as cultural establishments (theatres, museums, libraries, etc.) are rather varied and each has its own specificity.

In the modern world culture is very significant. It is viewed as the factor of spiritual health of people, social stability and national security as well as the factor of attractiveness of the territory for living and investments. To provide stable social and economic development of the state it is necessary to provide cultural investments in human capital. The growth of this capital is obtained to a great extent in the process of realization of cultural potential.

The state policy of the Russian Federation in the sphere of culture is aimed at preservation of the cultural heritage and the development of cultural diversity, at the increase of the level of people's involvement in cultural life and the development of cultural services for socially unprotected layers of the population.

In the conditions of the budget reforming and the introducing of the result oriented budgeting system one of the main tasks is effective and successful planning of budget spending. "Budget spending" is a fundamental economic category but modern economists don't have a single definition for it as it has different essential sides. The theoretical research of budget spending composition made it possible to formulate the following definition of their essence: economic relations connected with distribution of finance of any level of the budget system for financing of the functions of the legislative and executive power. Studying of the essence of budget spending assumes defining of ways to increase the results of this spending. So, it is possible to make a conclusion that the indicators of successfulness of budget spending reflect the correspondence of result to the goals and changes of the result during a certain period.

There are two ways to increase successfulness of budget spending: 
- to decrease expenditures;

- to reach high results in conditions of limited budget resources.

The first way assumes such spending of budget resources when expenditures for reaching some defined result are minimized and budget spending is successful. For example, this is the basis for the competitive system of state purchase. The most successful is the variant when the necessary amount of goods for the state use is purchased for the least price. But it will be too primitive to limit the problem of budget spending successfulness only by economy of budget resources.

The second way assumes reaching of the maximum result within the limits of some planned volume of budget resources. That means financing is based not on minimizing expenditures but on maximizing useful result. In this case full and quality satisfaction of public needs depends on successful budget spending.

According to the article 7 of the Constitution of the RF the Russian Federation is a social state which politics is aimed at creation of conditions providing good life and free development of a person including his educational and cultural level. Using the suggested definition of budget spending it is possible to define culture budget spending as economic relations connected with successful planned use of finance on socially valuable goals and tasks in the sphere of culture regulated by the norms of the budget legislation.

Goals and tasks in the sphere of culture in the Russian Federation are (Federal Targeted Programme "Russian Culture (2012 - 2018 )"): development and self-realization of a person, humanization of the society and preservation of national originality of peoples, creation and preservation of cultural securities and equal access to them for all citizens; development of democracy, strengthening of integrity and sovereignty of the Russian Federation, organization of international cultural cooperation and integration of native culture in the world culture.

The problem of increasing results of budget spending is especially actual as from the moment of formation of the modern Russian state the use of finance has not always been successful in spite of the increase of the volume of financing.

To characterize the process of development of budget spending management it is optimal to use division into periods which singles out three periods of the budget reform:

- $\quad$ the first period from 1990 to 2001 - the period of expenditures management;

- $\quad$ the second period from 2001 to 2008 - transition period;

- the third period from 2008 - the period of results management.

During the first period there was made a formation of three level budget system as well as the transition to treasury system of budget execution which made it possible to speed up the process of budget execution and to increase transparency and effectiveness of budget spending management. All these measures were very important for the increase of budget spending successfulness.

During the second period there was made a reform of inter-budget relations, a reform of budget accounting and changing of budget classification.

As for the third period, especially important was the federal law from May 8, 2010 № 83-FL "On the Introduction of Changes to Some Legislative Acts of the Russian Federation in Connection with the Improvement of the Legal Status of State (Municipal) Organizations" which defined three types of budget organizations: budget organization (with widened rights), autonomous organization and fiscal organization. Organizations of these types make it possible to use budget resources more successfully.

\subsection{Literature review}

Functional role of budget can't be viewed separately from the category of finance.

According to Khan and Jain, "finance is the art and science of managing money" (Khan. Jane, 2010) . Webster's Ninth New Collegiate Dictionary defines finance as 'the science on study of the management of funds' and the management of fund as the system that includes circulation of money, granting of credit, making of investments, and provision of banking facilities (Webster, 1983).

Summing up conceptual approaches of economists to the content and composition of finance, it is possible to make a conclusion that finance can be divided into two major parts (Paramasivan, 2009):

- private finance which includes individual, company, business or corporate financial activities;

- public finance which concerns revenue and disbursement of government such as central government, state government and semi-government financial matters. Taking into consideration the sphere of research and in order to use correct terminology, it is suggested to use the term "state finance" to characterize the essence and role of budget in it.

M. V. Romanovskiy defines budget as the system of imperative money relations between the state and other 
reproduction subjects on redistribution of part of public product cost in the process of use of finance to satisfy the most important needs of public reproduction on the given stage of development (Romanovskiy, Vrublevskaya, Sabanti, 2006).

Professor L.A. Drobozina characterizes budget as the main financial plan of the state which is equivalent to law. (Drobozina, 2001) .

Very often budget is characterized as "the form of creation and spending of money to provide the functions of governmental bodies". This approach was reflected in the Budget Code where budget is defined as "the formation and spending of money intended for provision of goals and tasks of the state and local government".

M.I. Tkachuk defines the budget as "political institution" and points out that "budget provides reproduction of the existing relations and is an important factor of realization of the democratic tradition" (Tkachuk, 1995). The most actual is the definition given by A.U. Kazak who shows that the concept of budget is many-sided and highlights that it is "the most important financial regulator (stabilizer) and the instrument of the state financial policy which influences all the social and economic processes by way of tax rates, volume, structure and direction of expenditures." According to A.U. Kazak budget forms final indexes of the economic system development (Kazak, 2012). We think that this definition not only reveals the economic gist of the budget but stresses its importance in the context of the general state policy.

I. N. Myslyaeva also views budget as relations: "budget means money relations between the state, legal entities and individuals on redistribution of the national profit in connection with the formation and use of money intended for financing of the national economy, social and cultural activities, defense industry and governance" (Myslyaeva, 2012). To our point of view this interpretation of "budget" is the most exact one. But the list of spending given by I.N. Myslyaeva is not full.

A.M. Babich tries to synthesize all the conceptions: "budget is a financial plan of the state, the form of creation and spending of money intended for providing activities of the state and local governance."(Babich, Pavlova, 1999) But we consider such approach to be not quite appropriate because it unites heterogeneous conceptions.

O.V. Sokolova solves the problem of synthesis of different definitions in another way. She thinks that the economic essence of budget is revealed through the totality of budget relations on forming and using the budget fund of a country. To her point of view there are three approaches to defining budget: first of all, budget is money relations between the state, individuals and legal entities; secondly, these relations arise on redistribution of national profit in connection with education and financing of economy, defense, state management, social and cultural events; thirdly, budget can be viewed as an independent category as it is the economic form of existence of objectively determined distribution relations (Sokolova, 2000). We think that such approach is rather significant as it reveals the economic essence of budget to the full.

Jonathan Gruber, in his "Public Finance and Public Policy" (Gruber, 2013) said, "The budget of a government is a summary or plan of the intended revenues and expenditures of that government. There are three types of government budget: the operating or current budget, the capital or investment budget, and the cash or cash flow budget."

The analysis of theoretical approaches let us define budget as a system of economic relations regulated by the norms of law and connected with formation and use of finance which are necessary for state and municipal bodies to provide and protect the interests of society and citizens. This definition makes it possible to highlight some basic moments which must be principal for revealing the economic essence of the budget.

First of all this definition highlights normative and legal status of federal, regional or local budgets and municipal level. It makes territory budget different from a budget of an enterprise. Budget relations on the state or municipal level can function only after corresponding legal acts are taken, that is in the form of legal relations regulating the processes of formation and use of centralized profit by state and municipal bodies in the form of taxes or in some other way. Only in such legal form money relations transform into budget relations which is the most important essential characteristic of budget as the category of state finance.

Secondly, it is important to displace the focus in the formulation of the main purpose of formation and distribution of money. In the previously cited interpretations of budget it was stated that budget is formed to make it possible for a state to perform its functions. This approach is more in line with command-administrative economy and the theory of state in which the interests of a state could be more important than the interests of a person and society.

Taking in consideration the subject of our research it seems necessary to study in detail the concept "budget spending". Financial science has not yet worked out a single definition of this concept.

"Budget spending" is money provided in a budget of a corresponding level for financing tasks and functions of governmental bodies and local government" (Vrublevskaya, Romanovskiy, 2008). This definition of Professor M.V. Romanovskiy characterizes material side of budget expenditures rather exactly. It is close to the definition given in the Budget Code of the Russian Federation: "Budget spending means money intended for financial providing of tasks and functions of the state and local government." 
V.M. Rodionova gives the following definition of budget spending: "Budget spending means economic relations arising in connection with distribution of money by governments and their use for some definite purposes, for the purposes of a territory or a brunch" (Rodionova, 2002). An important advantage of this definition is viewing budget expenditures as an economic category.

L.A. Drobozina thinks that "budget spending is expenditures caused by the fulfillment of its tasks and functions by the government. These expenditures express economic relations on the basis of which the government uses money means of the centralized fund on different purposes" (Drobozina, 2001). In this definition the accent is made mainly on expenditures and we think it must be made first of all on relations.

A.M. Babich and L.N. Pavlova concentrate their attention mainly on the fact that spending is a process: "Budget spending is the process of allocation and use of financial resources accumulated in budgets of all levels of the budget system in accordance with the laws on budgets for a financial year" (Babich, Pavlova, 1999). G.B. Polyak states that "budget spending means economic relations between a state on the one side and organizations, legal entities and individuals on the other side in course of use of centralized financial funds" (Polyak, 2012).

Public expenditure refers to Government expenditure i.e. government spending. It is incurred by central, state and local governments of a country.

"The expenditure incurred by public authorities like central, state and local governments to satisfy the collective social wants of the people is known as public expenditure". (Patil, 2013)

We consider budget spending to be economic relations arising on distribution of money on any level of a budget system for financial providing the functions of executive and legislative power bodies.

Taking into consideration the tasks of the research we would like to study the principle of effectiveness and successfulness in detail. We think it would be expedient to define "successfulness" as correlation between expenditures and results and "effectiveness" as profit from these results. So, it is possible to make a conclusion that the indices of successfulness of budget expenditures reflect the correspondence of a result to goals or changing of a result during a certain period.

The principle of successful use of budget finance is correlation of successful spending for achieving the goals of the budget policy of the Russian Federation and getting the largest volume of public benefits in conditions of limited budget resources. So, when making and fulfilling budgets authorized bodies and those who receive budget money should act on the premise that certain results must be achieved with the use of the least possible volume of finance or the best result must be achieved with the use of a certain volume of budget finance.

It is possible to achieve the increase of successfulness of budget spending in two ways:

- to decrease expenditures;

- to achieve high successfulness in conditions of limited budget recourses use

The first way suggests such use of budget means when expenditures on achieving certain results are minimized and budget spending is successful. This is the basis of competitive system of state purchases. The most successful is the variant when necessary volume of goods for public needs is purchased for the least possible price. But the problem of successfulness of budget spending can not be solved only by economy of budget means.

The second way suggests achieving maximum result with a planned volume of budget resources. That means financing is based not on minimizing expenditures but on maximizing the result. In this case full and quality fulfillment of collective needs in social benefits depends on successful functioning of the budget.

Nevertheless, the measurement of efficiency and effectiveness of public spending remains a conceptual challenge. Problems arise because public spending has multiple objectives and because public sector outputs are often not sold on the market which implies that price data is not available and that the output cannot be quantified (Mandl, Dierx, Ilzkovitz, 2008). Furthermore, cross-country differences exist in terms of the source of public funding (financing instruments) (Afonso, Aubyn, 2006). Finally, expenditures in one domain tend to be related to the level of total spending in the country or to the level of economic development. Similar difficulties occur with respect to output, since countries have both different starting points and priorities (e.g. quality requirements) (Herrera, Pang, 2005).

\section{Materials and Methods}

We studied the problems of planning and financing of culture spending in a subject of the Russian Federation and analyzed the planning of expenditures on culture taking Samara Region as an example.

Budget process includes making, discussing, approving and fulfillment of a budget project in order to achieve successful and effective financing of state activities.

Financial support of cultural sphere is carried out in accordance with the section "Culture, Cinematography and 
Mass Media" of the functional classification of expenditures:

- Culture;

- Cinematography;

- TV and radio;

- Printed media and publishing houses;

- Scientific research in the sphere of culture, cinematography and mass media;

- Other spending in the sphere of culture, cinematography and mass media.

Analysis of financing of the cultural sphere in Samara Region has shown that there is a tendency to increase expenditures on culture from the regional budget. It is especially notable for the year 2008 because of the financing of reconstruction of the state cultural establishment Samara Academic Opera and Ballet Theatre, a priority object of the budget policy of Samara Region (Table 1).

Besides, the data on financing of expenditures by the Ministry of Culture of Samara Region during the last five years show the discrepancy of planned and factual financing. The medium level of use of the budget financing during the period from 2005 to 2013 was $96 \%$, so we can make a conclusion that there is no stable and successful planning.

Table 1. Regional Culture Budget Spending of the Samara Region For the period of 2005-2014 years

\begin{tabular}{|c|c|c|c|}
\hline Year & Approved for the year, million rubles & Fulfilled for the year, million rubles & Fulfilled, $\%$ \\
\hline 2005 & 452 & 445 & 96 \\
\hline 2006 & 473 & 450 & 88 \\
\hline 2007 & 511 & 476 & 93 \\
\hline 2008 & 2936 & 2819 & 97 \\
\hline 2009 & 671,6 & 671 & 99 \\
\hline 2010 & 657 & 650 & 98,9 \\
\hline 2011 & 1379 & 1282 & 92 \\
\hline 2012 & 1678 & 1623 & 96,7 \\
\hline 2013 & 1774 & 1763 & 99,3 \\
\hline 2014 & 1488 & - & - \\
\hline
\end{tabular}

The lowest proportion in the budget of Samara Region Ministry of Culture falls on such expenditures as financial support of Samara Region Ministry of Culture (4\%), preservation of cultural heritage objects and strengthening of the material and technical base (6\% and $8 \%$ correspondingly). The biggest proportion of the expenditures falls on salaries of cultural establishments staff (30\%), carrying out of cultural events (27\%) and financial support of subordinated institutions (25\%) (Table 2).

Table 2. Distribution of Budget Resources in the Ministry of Culture of Samara Region, thousands of rubles

\begin{tabular}{|l|c|c|c|c|c|c|c|c|c|}
\hline Expenditures & 2006 & 2007 & 2008 & 2009 & 2010 & 2011 & 2012 & $\begin{array}{c}2013 \\
\text { On } \\
\text { average, } \\
\%\end{array}$ \\
\hline Salaries of subordinated institutions staff & 165000 & 167000 & 491000 & 230445 & 226288 & 545311 & 591610 & 613873 & 30 \\
\hline Financial support of subordinated institutions & 120046 & 122050 & 902461 & 162050 & 160128 & 446608 & 503212 & 572214 & 25 \\
\hline $\begin{array}{l}\text { Provision of activities of Samara Region Ministry of Culture } \\
\begin{array}{l}\text { Strengthening of the material and technical base of } \\
\text { subordinated institutions }\end{array}\end{array} 211700$ & 23700 & 39184 & 25700 & 42560 & 48524 & 47922 & 52357 & 4 \\
\hline $\begin{array}{l}\text { Preservation, use and popularization of cultural heritage } \\
\text { objects (cultural and historical monuments) }\end{array}$ & 18487 & 12543 & 1165300 & 22543 & 21241 & 27314 & 29527 & 36587 & 6 \\
\hline Carrying out of cultural events & 129978 & 134170 & 2049350 & 219728 & 196844 & 149381 & 241157 & 117076 & 27 \\
\hline Total & 466754 & 476000 & 2819000 & 671000 & 657000 & 1282716 & 1623000 & 1763112 & 100 \\
\hline
\end{tabular}

Practical implementation of budgeting oriented towards results has brought to life such instruments as registers of expenditure commitments of the government, justifications of budget allocations, targeted programmes, state and municipal tasks.

Register of expenditure commitments is a set of normative legal regulations and contracts made by a subject of budget planning according to which expenditure commitments are paid at the expense of the budget of a budget planning subject in accordance with the legislation of the Russian Federation. This includes expenditures of the most important scientific, educational, cultural and medical institutions as well as mass media. The volume of budget means necessary 
for the fulfillment of the commitments must be pointed out.

Justification of budget allocations is needed for linking budget allocations in the medium term perspective with indices of the results. Preparation of this justification is performed in order to justify corrections in budget projects within the frame of medium term planning; to justify volumes of budget allocations oriented towards the result on the level of targeted expenditures in medium term perspective with pointing out the main factors influencing the correction to be made.

Targeted programme is the complex of events connected with each other and aimed at the fulfillment of a concrete tactical task. Data on the fulfillment of targeted programmes including measures to increase successfulness of financing are given in the reports on the results and the main directions of activities.

State (municipal) task is a document establishing requirements to the contents, quality, conditions, order and results of state (municipal) services. State task is formed in accordance with Articles of Association of budget institutions, autonomous institutions and other non-commercial organizations and is used when planning budget allocations on state services for legal entities and individuals. When forming state task several factors are taken into consideration such as indices of factual fulfillment of state task in financial year, material, technical and human resources of an institution, forecasted need in this or that service and the level of satisfaction by the volume and quality of a service. In Samara Region state tasks for institutions of cultural sphere, an important method of achieving successfulness of budget spending, are used from 2006.

Active use of budgeting methods oriented towards result by the Ministry of Culture of Samara Region made it possible to increase responsibility of the heads of budget institutions for the services performed and successfulness of use of budget means despite some decrease of the level of financing caused by the last world economic crises.

When planning and financing expenditures on culture it is necessary to take into consideration specific characteristics of each category of cultural institutions. For example, to create a ballet (decorations, costumes, orchestra, etc.) more money is needed than to create a drama play.

Analysis of planning and financing expenditures on state cultural institutions of Samara Region, such as Samara State Philharmonic Society, Samara Drama Theatre named after Gorkiy, Samara Regional Library for Blind People, Samara Regional Museum of Local History named after P.V. Alabin, International Centre of Culture Development in Samara Region revealed some additional financial sources of profit from commercial activities and paid services and the need of a single mechanism of their distribution by cultural institutions. So, it is necessary to develop a single method of estimation of successfulness of spending on the basis of a universal system of indices.

The analysis of planning and financing budget spending showed that at present they are not highly effective in Samara Region though financing is close to planned one.

To our point of view it is necessary to take some measures to improve planning, financing and making spending in cultural sphere more effective:

1. Introduction of mechanism of private-state partnership is a measure which promotes elimination of infrastructural limits of cultural institutions financing. It creates optimal conditions for investing in long-term projects and increases internal and external investments in the sphere of culture.

Private-state partnership is the most important and universal mechanism of investment policy. It promotes consolidation of financial, organizational and management potential of state and private sectors of the economy in priority spheres. This mechanism unites financial resources of the state, municipal education and business that has financial means for making investments. For cultural institutions which got the status of budget institution with wider volume of rights, the use of mechanism of private-state partnership makes it possible to get additional means for achieving and increasing successfulness.

2. Reorganization of such cultural institutions as theatres, concert halls, museums and philharmonic societies from budget institutions into autonomous to achieve financial independence and the ability to use finance from commercial activities independently.

Such measure is necessary because financing of culture is made not only at the expense of the budget but also from commercial activities of cultural institutions and this additional profit is used by them independently.

3. The use of method of successfulness and effectiveness of results estimation.

Estimation of results of budget institution financing is one of the main constituents of budget means planning. It means the process of monitoring the quality of work of those who use budget means in order to increase the successfulness of this work.

We worked out a number of indicators to estimate the successfulness of spending. The system of indicators includes four blocks reflecting the successfulness of work of cultural institutions from position of economic successfulness and effectiveness. Social factors were taken into consideration. 
The indicators are divided into financial, HR, social and quality indicators (Fig. 1). Financial indicators characterizing direct results are the proportion of profit from entrepreneurship and other activities in the total sum of expenditures of cultural institutions for a certain period; profit from trade of $c$ goods for cultural purposes, deviation of real budget expenditures from planned ones, etc. HR indicators include the level of fluctuation of human resources and the proportion of specialists with higher education. Social results must be measured by the number of persons involved in social and cultural activities.

Specific character of cultural activities stipulates the importance of indicators of services quality. For libraries it is the number of readers, renovation of funds, the number of books. For other cultural institutions it can be attendance, renovation of repertoire, the proportion of spectators in 10000 people.

Qualitative estimation can be obtained on the basis of sociological methods which allow to:

- study the opinion of the population (interviews, questionnaires) and to see the level of satisfaction with cultural services;

- get estimation of professional experts.

The results of interviewing of the population together with the results of professional expertise give a possibility to make ratings.

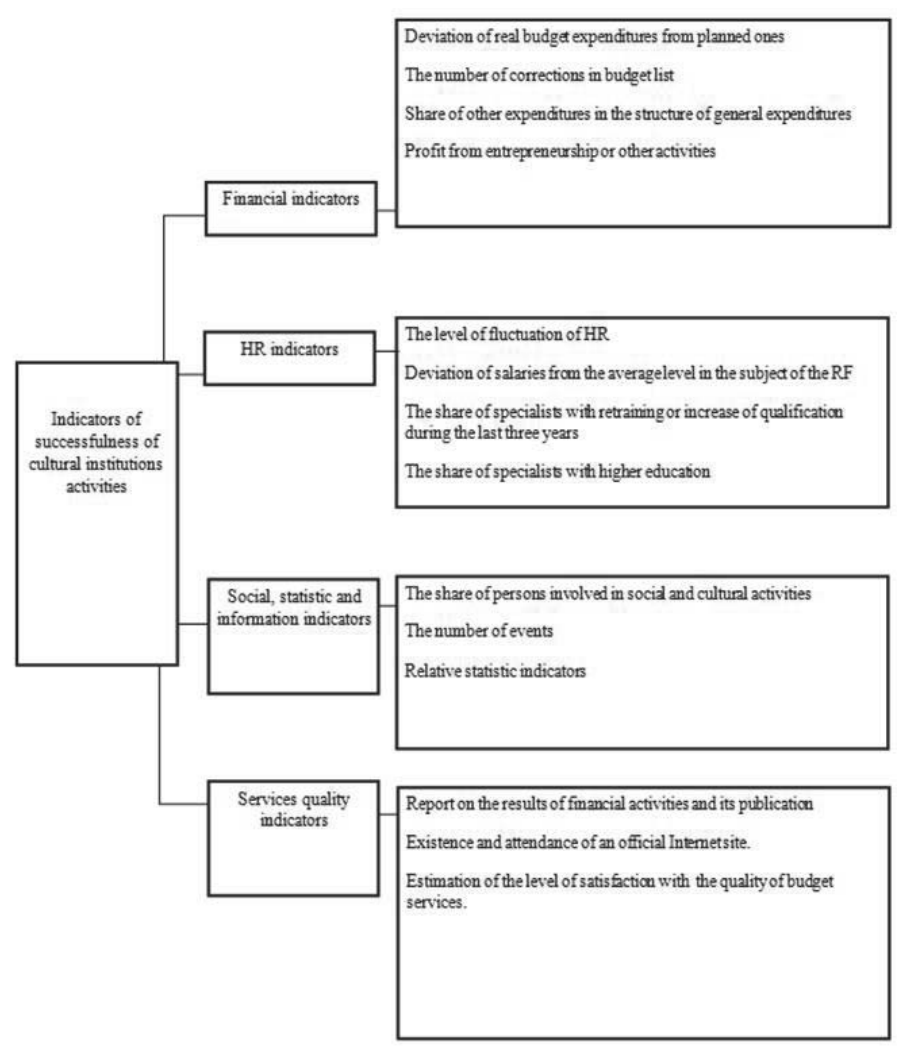

Figure 1. System of Indicators of a Cultural Institution Results Estimation

Estimation of results of financing cultural institutions with the use of the above-mentioned indicators allows to make complex analysis of results of cultural institutions in several directions: estimation of direct results (social, economic and financial) and estimation of qualitative effectiveness.

To make such analysis we worked out the method of estimation of successfulness of financing cultural institutions based on the use of the system of indicators.

For complex analysis one can use both indicators and their integral estimation. Method of calculation of integral 
index of successfulness of budget spending on culture. This method allows to correct the system of indicators, include additional indicators and exclude those which are not needed at the moment.

We suggest using the following number of indicators

- financial indicators - 7-10 indicators;

- human resources indicators - 5-7 indicators;

- social indicators - 3-5 indicators;

- quality indicators - 5-10 indicators.

The total number of indicators can be from 10 to 30 . Indicators can be positive or negative answer to the question, number or percentage.

The suggested method of estimation of successfulness and effectiveness of budget spending is represented on Figure 2.

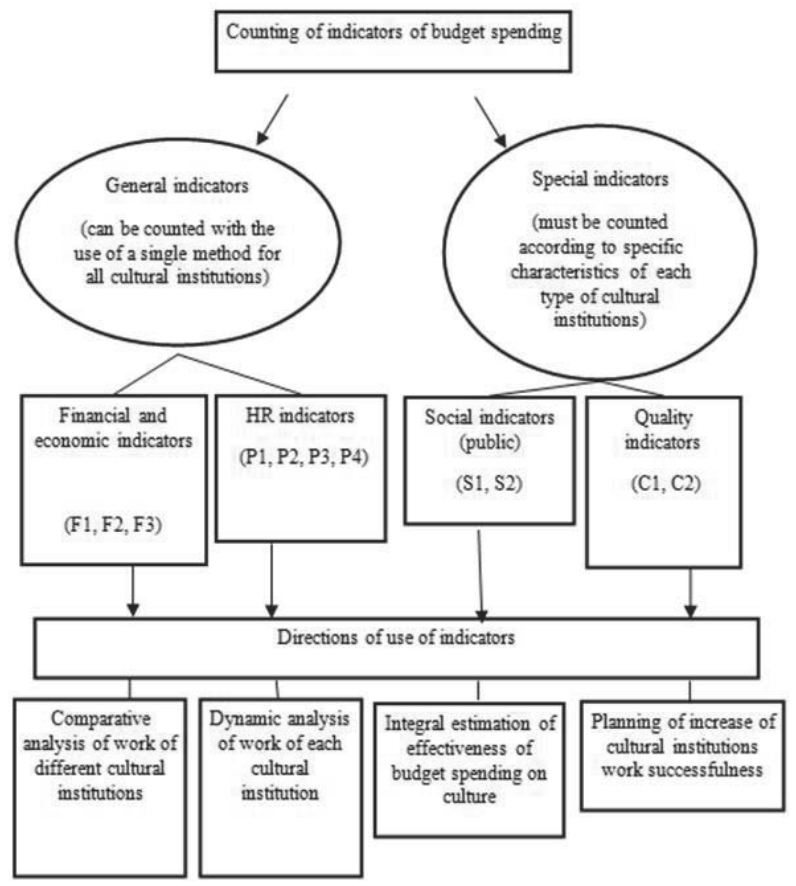

Figure 2. Method of Estimation of Results of Culture Budget Spending of the Subject of the Russian Federation

The first block of indicators includes calculation of financial indicators:

Indicator F1. Deviation of real regional budget expenditures of the receiver of budget means from planned ones during the period.

Indicator F2. The number of corrections in the budget list (for the receiver) during the period.

Indicator F3.The share of other current expenditures in the structure of current expenditures.

The next group of indicators are human resources indicators:

Indicator P1. The share of specialists with higher education.

Indicator P2. Deviation of the average salary of cultural institution personnel from the average salary in the subject of the Russian Federation.

Indicator P3. The share of specialists chosen on competitive basis.

Indicator P4. The level of fluctuation of human resources.

Indicators which characterize social significance of work of a cultural institution, transparency of information concerning the results of work for the population:

Indicator S1. Publication of reports on the results of work in mass media. 
Indicator S2. Existence of an official Internet site of a cultural institution.

Indicator S3. The share of respondents who consider the quality of services of the given cultural institution satisfactory.

Indicators of quality:

Indicator $\mathrm{C} 1$. The rates of increase of the share of persons involved in social and cultural activities.

Indicator $\mathrm{C} 2$. The number of social and cultural events.

To our point of view the method of estimation of budget spending results must correspond to the following requirements:

- It must reflect the targeted result of activities of the main user of budget means in the concrete direction (to be oriented towards result);

- It must provide information necessary for the estimation of quality of budget spending management and optimization of procedures of making managerial decisions in budget;

- It must be simple to fix numbers, to calculate and interpret;

- Indicators must be comparable. They must allow to make interbranch comparison of changing dynamics numbers of the indicators.

Financial, human resources and social indicators can be unified for all cultural institutions of differ a little. Special indicators must be worked out individually for each type of cultural institutions (theatres, museums, agencies, etc.)

In the basis of the method there are the following principles: indicators are divided into four blocks (financial, human resources, social and special); using both quality and quantity indicators and weighed mark estimation of results.

\section{Results and Discussion}

To show the calculation of indicators let's have a look at the results of work of the state institution International Centre of Culture Development in Samara Region.

The first block of indicators includes the calculation of financial indicators.

Indicator F1. Deviation of real regional budget expenditures of the receiver of budget means from planned ones during the period.

It is calculated according to the formula:

$\mathrm{F} 1=((\mathrm{Ef}-\mathrm{Ep}) / \mathrm{Ep}) \star 100 \%$

Where $\mathrm{Ef}-$ factual expenditures of the receiver during the period, thousands of rubles; Ep - planned expenditure during the period according to department structure of the regional budget expenditures during the period in the initial list, thousands of rubles.

Let's make analysis with the use of indicators of the factual expenditures of International Centre of Culture Development in Samara Region in 2013: factual expenditures- 10415000 rubles, planned expenditures - 9259000 rubles

$\mathrm{F} 1=((10415-9259) / 9259) * 100 \%=12 \%$

On the basis of the value of the indicator F1 it gets marks according to the Table 3.

Table 3. Marks for the indicator F1

\begin{tabular}{|c|c|c|c|}
\hline \multicolumn{2}{|c|}{ Factual value of the identificator } & Mark & Weight \\
\hline From $-100 \%$ to $-25 \%$ & From $25 \%$ to $100 \%$ & 0,25 & \multirow{2}{*}{3} \\
\cline { 1 - 2 } From $-25 \%$ to $-10 \%$ & From $10 \%$ to $25 \%$ & 0,5 & \\
\hline From $-10 \%$ to $-5 \%$ & From $5 \%$ to $10 \%$ & 0,75 & \\
\hline From $-5 \%$ to $0 \%$ & From $0 \%$ to $5 \%$ & 1 & \\
\hline
\end{tabular}

For this indicator the best variant is when cash expenditures are maximally close to the planned ones. Big deviations are undesirable.

In the example above the deviation is $12 \%$, so the mark according to the table is 0,5 . Weighed mark is $1,5\left(3^{\star} 0,5\right)$.

Indicator F2. The number of corrections in the budget list (for the receiver) during the period. This indicator allows to estimate the quality of planning of budget spending and the level of budget discipline. The mark is calculated according to the Table 4. 
Table 4. Marks for the indicator F2

\begin{tabular}{|l|c|c|}
\hline Factual value of the identificator & Mark & \multirow{2}{*}{ Weight } \\
\hline More than 10 & 0,25 & \multirow{2}{*}{2} \\
\cline { 1 - 2 } From 6 to 10 & 0,5 & \\
\cline { 1 - 2 } From 3 to 5 & 0,75 & \\
\hline Less than 2 & 1 & \\
\hline
\end{tabular}

12 corrections were made in the budget list of International Centre of Culture Development in Samara Region during the year. In this case unweighed mark of the indicator F2 will be 0,25 . Weighed mark: $0,5(0,25 \star 2)$.

Indicator F3. The share of other current expenditures in the structure of current expenditures. This indicator allows to reveal and decrease the share of non-transparent budget expenditures.

It is calculated according to the formula:

$\mathrm{F} 3=(\mathrm{E} / \mathrm{Ef}) * 100 \%$

Eo - other current expenditures of a cultural institutions, thousands of rubles.

Ef - factual expenditures for the period, thousands of rubles.

Other expenditures are 466000 rubles, factual expenditures are 10415000 rubles. So:

$\mathrm{F} 3=(466 / 10415) * 100 \%=4 \%$

On the basis of this value we can calculate the mark of indicator F3 according to Table 5.

Table 5. Marks for the indicator F3

\begin{tabular}{|l|c|c|}
\hline Factual value of the identificator & Mark & \multirow{2}{*}{ Weight } \\
\hline More than 10 & 0,25 & \multirow{2}{*}{2} \\
\cline { 1 - 2 } From 6 to 10 & 0,5 & \\
\cline { 1 - 2 } From 3 to 5 & 0,75 & \\
\hline Less than 2 & 1 & \\
\hline
\end{tabular}

Unweighed mark is 0,75 . Weighed mark is 1,5 .

This indicator allows to reveal the volume of budget means distributed outside the budget classification which can not be analyzed by higher authorities. Big volumes of "other expenses" show that the activities of the institution are not transparent.

The next group of indicators consists of human resources indicators.

Indicator P1. The share of specialists with higher education. It is calculated according to the formula:

$\mathrm{P} 1=(\mathrm{Pe} / \mathrm{Pt})^{\star} 100 \%$

Where $\mathrm{Pe}$ is the number of specialists with higher education.

$\mathrm{Pt}$ is the total number of personnel of the institution of culture.

The number of specialists of International Centre of Culture Development in Samara Region is 21 persons. The number of specialists with higher education is 18 persons.

$\mathrm{P} 1=(18 / 21) \star 100 \%=85,7 \%$

On the basis of this value we can calculate the mark of the indicator according to Table 6 .

Table 6. Marks for the indicator P1

\begin{tabular}{|l|c|c|}
\hline Factual value of the identificator & Mark & Weight \\
\hline From 0 to $70 \%$ & 0,25 & \multirow{2}{*}{2} \\
\cline { 1 - 2 } From 70 to $80 \%$ & 0,5 & \\
\cline { 1 - 2 } From 80 to $90 \%$ & 0,75 & \\
\hline More than $90 \%$ & 1 & \\
\hline
\end{tabular}

Unweighed mark is 0,75 . Weighed mark is $1,5\left(0,75^{\star} 2\right)$.

This indicator makes it possible to estimate the human resources of an institution. A large share of specialists with higher education shows good human resources politics and high qualification of specialists which in its turn allows to increase effectiveness and successfulness of spending. 
Indicator P2. Deviation of the average salary of cultural institution personnel from the average salary in the subject of the Russian Federation.

It is calculated according to the formula:

$\mathrm{P} 2=((\text { Salf-Salr }) / \text { Salr })^{\star} 100 \%$

Where Salf is an average salary of the personnel of a cultural institution for the period, thousands of rubles.

Salr - an average salary in the region.

The average salary of International Centre of Culture Development in Samara Region in 2013 was 19000 rubles per month. The average salary in the region was 24000 per month.

$\mathrm{P} 2=((19-24) / 24) * 100 \%=-20 \%$

On the basis of this value we can calculate the mark of the indicator according to Table 7.

Table 7. Marks for the indicator P2

\begin{tabular}{|l|l|c|c|}
\hline \multicolumn{2}{|l|}{ Factual value of the identificator } & Mark & \multirow{2}{*}{ Weight } \\
\hline Less than 35\% & More than 35\% & 0,25 & \multirow{2}{*}{3} \\
\cline { 1 - 3 } From 35 to 20\% & From 20 to 35\% & 0,5 & \\
\cline { 1 - 3 } From 20 to10\% & From 10 to 20\% & 0,75 & \\
\hline From10 to 0\% & From 0 to 10\% & 1 & \\
\hline
\end{tabular}

Unweighed mark is 0,5 . Weighed mark is $1,5\left(3^{\star} 0,5\right)$.

This indicator helps to reveal deviation of the average salary of cultural institution specialist from the average salary in the region. The fact that the average salary of a specialist is less than the average salary in the region can cause problems with attraction of human resources and social discomfort of the personnel. But when an average salary of personnel of a cultural institution is much bigger than an average salary in the region it can be a sign that expenditures on salary payment can be cut.

Indicator P3. The share of specialists chosen on competitive basis. It is calculated according to the formula:

$\mathrm{P} 3=(\mathrm{Pcon} / \mathrm{Pt}) * 100 \%$

Where Pcon is the number of specialists chosen on competitive basis.

$\mathrm{Pt}$ is the total number of specialists employed during the current period.

On the basis of the value of the indicator P3 we can calculate the mark of the indicator according to Table 8.

Table 8. Marks for the indicator P3

\begin{tabular}{|l|c|c|}
\hline Factual value of the identificator & Mark & \multirow{2}{*}{ Weight } \\
\hline From 0 to $20 \%$ & 0,25 & \multirow{2}{*}{2} \\
\cline { 1 - 2 } From 20 to $40 \%$ & 0,5 & \\
\cline { 1 - 2 } From 40 to $70 \%$ & 0,75 & \\
\hline More than $70 \%$ & 1 & \\
\hline
\end{tabular}

We do not calculate this indicator because of the absence of data on International Centre of Culture Development in Samara Region.

Then we suggest such human resources indicator as $\mathrm{P} 4$, which is very important to our point of view. It is the level of fluctuation of human resources in the cultural institution. It is calculated according to the formula:

$\mathrm{P} 4=(\mathrm{Pg} / \mathrm{Pm}){ }^{\star} 100 \%$

$\mathrm{Pg}$ is the number of specialists who resigned during the period;

$\mathrm{Pm}$ - the total number of specialists during the period according to the list.

On the basis of the value of the indicator P4 we can calculate the mark of the indicator according to Table 9.

Table 9. Marks for the indicator P4

\begin{tabular}{|l|c|c|}
\hline Factual value of the identificator & Mark & \multirow{2}{*}{ Weight } \\
\hline More than $20 \%$ & 0,25 & \multirow{2}{*}{3} \\
\cline { 1 - 2 } From 10 to $20 \%$ & 0,5 & \multirow{2}{*}{3} \\
\hline From 5 to $10 \%$ & 0,75 & \\
\hline From 0 to 5\% & 1 & \\
\hline
\end{tabular}


We do not calculate this indicator because of the absence of data on International Centre of Culture Development in Samara Region. Normal level of fluctuation of human resources is 3-5\%. If fluctuation is higher it influences negatively the work of a budget institution. Fluctuation of personnel causes increase of expenditures and decrease of effectiveness of work as productivity of labour is lower during the period of adaptation.

Then we calculate indicators which characterize social significance of cultural institution work and transparency of information about the results of this work for the population.

Indicator S1. Publication of reports on the results of work in mass media.

The value of the indicator is defined according to Table 10.

Table 10. Marks for the indicator S1

\begin{tabular}{|c|c|c|}
\hline Factual value of the identificator & Mark & Weight \\
\hline No & 0 & 1 \\
\hline Yes & 1 & \\
\hline
\end{tabular}

The reports on the work of International Centre of Culture Development in Samara Region are published in mass media.

Unweighed mark is 1 . Weighed mark is 1.

Publishing official reports in mass media characterize the work of the cultural institution positively. The population is able to estimate the results of the budget spending.

S2. Existence of an official Internet site of a cultural institution.

The value of the indicator is defined according to Table 11.

Table 11. Marks for the indicator S2

\begin{tabular}{|c|c|c|}
\hline Factual value of the identificator & Mark & Weight \\
\hline No & 0 & 2 \\
\hline Yes & 1 & \\
\hline
\end{tabular}

International Centre of Culture Development in Samara Region has an official site in the Internet

Unweighed mark -1. Weighed mark -1. to define:

In future monitoring of budget spending must include the data of sociological interviews. This information will help

- the ways to improve the quality and characteristics of services;

- the use of this or that service;

- $\quad$ the attitude of customers to the services, satisfaction by the services;

- the actions of customers after the termination of services;

- the rating of quality characteristics of services;

- the reasons of dissatisfaction with the service (refusal to get the service).

We think that the research of customer's opinion is not only the way to estimate the activities of a cultural institution but also the ability to attract the population to the problem of financing of cultural sphere in general.

On the basis of sociological interviewing it is possible to calculate the indicator S3.

Indicator S3. The share of respondents who consider the quality of services of the given cultural institution satisfactory.

S3 $=(\text { Pos/Tot) })^{*} 100 \%$

Pos is the number of respondents who consider the quality of services of the given cultural institution satisfactory.

Tot - total number of respondents.

Marks for the indicator are calculated according Table 12.

Table 12. Marks for the indicator S3

\begin{tabular}{|l|c|c|}
\hline Factual value of the identificator & Mark & Weight \\
\hline Less than $50 \%$ & 0,25 & \\
\cline { 1 - 2 } From 50 to $70 \%$ & 0,5 & \multirow{2}{*}{3} \\
\hline From 70 to $80 \%$ & 0,75 & 1 \\
\cline { 1 - 2 } More than $80 \%$ & & \\
\hline
\end{tabular}


In this case the coefficient is not calculated (0).

Special indicators must be worked out for each type of a cultural institution taking into consideration its specific character.

When working out special indicators we think it is reasonable comply with the following principles:

1. Sufficiency of information. The indicators must be calculated on the basis of statistical data. In other case getting additional data will lead to the increase of budget spending on monitoring.

2. Targeted character. The indicators must reflect targeted result of the activities of a cultural institution in a concrete direction of budget spending.

Let's view the values of the two main indicators taking as the example the results of the activities of International Centre of Culture Development in Samara Region for the year 2013.

Indicator $\mathrm{C} 1$. The rates of increase of the share of persons involved in social and cultural activities.

$\mathrm{C} 1=(\mathrm{InC} \mid \mathrm{T} / \mathrm{InCl}) \star 100 \%$

Where IncIT is the number of persons involved in social and cultural activities during the current period.

Incl is the number of persons involved in social and cultural activities during the basic period

The value is defined according to Table 13.

Table13. Marks for the indicator $\mathrm{C} 1$

\begin{tabular}{|l|c|c|}
\hline Factual value of the identificator & Mark & Weight \\
\hline Less than $100 \%$ & 0,25 & \multirow{2}{*}{10} \\
\cline { 1 - 2 } From 100 to $110 \%$ & 0,5 & \\
\cline { 1 - 2 } From 110 to $150 \%$ & 0,75 & \\
\hline More than $150 \%$ & 1 & \\
\hline
\end{tabular}

In this case 126000 people from Samara Region were involved in social and cultural activities in the year 2013 and 63000 people - in the year 2012.

$\mathrm{C} 1=(126 / 63)^{\star} 100 \%=200 \%$

Unweighed mark is 1 . Weighed mark is 10.

The increase of the number of persons involved in social and cultural activities due to the events organized by International Centre of Culture Development in Samara Region characterize the activities of the Centre positively.

Indicator C2. The number of social and cultural events.

$\mathrm{C} 2=(\mathrm{Ev} / \mathrm{EvT}))^{\star} 100 \%$

Where $\mathrm{Ev}$ is the number of events organized in the current period.

EvT is the number of events in the basic period. The value of the indicator is calculated according to Table 14.

Table 14. Marks for the indicator C2

\begin{tabular}{|l|c|c|}
\hline Factual value of the identificator & Mark & Weight \\
\hline Less than $100 \%$ & 0,25 & \multirow{2}{*}{10} \\
\cline { 1 - 2 } From 100 to $110 \%$ & 0,5 & \\
\cline { 1 - 2 } From 110 to $120 \%$ & 0,75 & \\
\cline { 1 - 2 } More than $120 \%$ & 1 & \\
\hline
\end{tabular}

In 201323 social and cultural events were held at the expense of the regional budget. In 2012 - 22 events were held.

$\mathrm{C} 2=(22 / 23) * 100 \%=104 \%$

Unweighed mark is 0,5 . Weighed mark is 5 .

Only calculated values are included in it. Indicators which were not calculated have zero value.

Using this method it is easy to reveal strong and weak sides in the work of any type of cultural institutions. If unweighed mark is 1 ? The activities of the budget means receiver are optimal on this criteria.

In particular in the activities of International Centre of Culture Development in Samara Region we can estimate positively:

- the use of methods of programme targeted planning (when planning expected results are defined, not only expenditures);

- official reports on the activities of the institution in mass media and the Internet and free access of the 


\section{population to it;}

- stable increase of the number of persons getting social and cultural services of the institution.

In this case if the mark is 1 , the activities are optimal. The calculation of successfulness of culture budget spending was made with the use of this method on the example of the data on the financing of the state institution International Centre of Culture Development in Samara Region for the year 2013 (Table 15).

Table 15. Calculation of the Integral Indicator of Successfulness of Budget Spending of International Centre of Culture Development in Samara Region for the year 2013.

\begin{tabular}{|c|c|c|c|}
\hline Indicator & $\begin{array}{c}\text { Mark } \\
(I)\end{array}$ & $\begin{array}{l}\text { Weight } \\
(W)\end{array}$ & $\begin{array}{l}\text { Value } \\
(W \cdot I)\end{array}$ \\
\hline $\begin{array}{l}\text { Indicator F1. Deviation of real regional budget expenditures of the receiver of budget means from planned ones during } \\
\text { the period, \% }\end{array}$ & 0,5 & 3 & 1,5 \\
\hline Indicator F2. The number of corrections in the budget list (for the receiver) during the period. & 0,25 & 2 & 0,5 \\
\hline Indicator F3.The share of other current expenditures in the structure of current expenditures. & 0,75 & 2 & 1,5 \\
\hline Indicator P1. The share of specialists with higher education. & 0,75 & 2 & 1,5 \\
\hline $\begin{array}{l}\text { Indicator P2. Deviation of the average salary of cultural institution personnel from the average salary in the subject of the } \\
\text { Russian Federation. }\end{array}$ & 0,5 & 3 & 1,5 \\
\hline Indicator P3. The share of specialists chosen on competitive basis. & 0 & 0 & 0 \\
\hline Indicator P4. The level of fluctuation of human resources. & 0 & 0 & 0 \\
\hline Indicator S1. Publication of reports on the results of work in mass media. работы в СМИ & 1 & 1 & 1 \\
\hline Indicator S2. Existence of an official Internet site of a cultural institution. & 1 & 2 & 2 \\
\hline Indicator C1. The rates of increase of the share of persons involved in social and cultural activities. & 1 & 10 & 10 \\
\hline Indicator C2. The number of social and cultural events. & 0,5 & 10 & 5 \\
\hline Total & - & 35 & 24,5 \\
\hline
\end{tabular}

On the basis of calculation of indicators it is possible to calculate integral (total) mark of budget spending results. Each indicator has weight $(W)$. The total mark is calculated according to the formula:

$E f f=\left(\sum\left(W_{i}-l_{i}\right) / \sum W_{i}\right) \cdot 100 \%$

Where Eff is an integral estimation of budget spending results;

$W_{i}$ is the weight of an indicator in the result;

$l_{i}$ is the value of an indicator, mark.

In this example the level of effectiveness of budget spending of International Centre of Culture Development in Samara Region is:

$E f f=((35-24,5) / 35) \cdot 100 \%=30 \%$.

On the basis of this calculated value (Eff) we can find the total level of successfulness of budget spending (Table 16).

Table16. Defining the Level of Budget Spending Successfulness of the Cultural Institution Depending on the Value of the Integral Indicator (Eff) for the year 2013

\begin{tabular}{|l|c|}
\hline Level & Value Eff, $\%$ \\
\hline Critical & From 0 to 30 \\
\hline Low & From 30 to 60 \\
\hline Medium & From 60 to 80 \\
\hline Optimal & More than 80 \\
\hline
\end{tabular}

We can make a conclusion that the successfulness of financing of International Centre of Culture Development in Samara Region in 2013 can be estimated as low.

As for the years 2005-2012 the analysis showed that the successfulness of financing of International Centre of Culture Development in Samara Region can also be estimated as low (Eff $=30 \%$ in 2005 , Eff $=32 \%$ in 2006, Eff $=31 \%$ in 2007, Eff $=39 \%$ in $2008, E f f=38 \%$ in $2009, E f f=39 \%$ in 2010, Eff $=43 \%$ in 2011, Eff $=44 \%$ in 2012 ).

Measurement of efficiency and effectiveness are highly sensitive to the data sets being used. The data used for international comparisons require a minimum level of homogeneity. Nevertheless, it is unavoidable that such data reflect the different organizations and traditions of government and therefore are not fully comparable between countries. For example, the different national boundaries between the public and the private sector could give rise to a rather misleading picture in cross-country investigations (Farrell, 1957) 
The method has the following advantages:

- it is possible to calculate not only the integral indicator of successfulness but also particular indicators (in the majority of methods it is possible to calculate either particular or integral);

- the approach is universal (when you change special indicators the system can be used for any type of cultural institutions);

- the system of indicators is flexible (if there is no information on some indicators, less number of indicators can be used)

The suggested method of estimation of successfulness and effectiveness of budget spending on culture by the subjects of the RF on the basis of the system of indicators of expenditures financing promotes more profound analysis as it takes into consideration specific character of cultural institutions, their heterogeneity and wide spectrum of their activities. The use of the suggested indicators will make it possible to increase the successfulness and effectiveness of financing cultural institutions, will optimize the process of culture budget planning.

The results of our calculations define the following directions of increasing successfulness and effectiveness of culture budget spending;

- $\quad$ salary increase for decreasing human resources fluctuation and stimulating interest in the results of work;

- increase of effectiveness of specific activities of a cultural institution.

Thus, our method of estimation of results promotes revealing and solving of the problems connected with planning and financing of culture budget spending on the modern stage of the economic development and their transformation in the long-term perspective; peculiarities of budget reforms realization in the regions and the need to achieve and increase successfulness of culture budget spending in Samara Region.

\section{Conclusion}

One of the main goals of the budget policy is further reformation of the budget system, its orientation towards stimulation of the constant growth and providing of social sphere functioning. The increase of successfulness of budget spending is first of all connected with transformations in the sphere of the budget process.

State policy in the sphere of cultural development in the Russian Federation is oriented towards preservation of cultural heritage and development of cultural diversity, increase of people's involvement in cultural life, broadening the range of cultural services of socially unprotected layers of the population.

But in conditions of instability of economy stipulated by the financial crises the problems of planning and financing of culture budget spending are very actual. It is important to know how far a given industry can be expected to increase its output by simply increasing its efficiency, without absorbing further resources (Afonso, Schuknecht, Tanzi, 2005).

As a result of the research the following conclusions were made:

1. In the modern economic literature there is no unanimity as far as definition of "budget spending" is concerned. This category is interpreted differently by many scientists in the sphere of economics.

Some authors view expenditures arising when the state performs its tasks and functions as the essence of "budget spending". The other identify budget expenditures with the relations connected with distribution and use of financial resources. In the given research the definition of budget spending is formulated from the position of effectiveness of spending as economic relations connected with distribution of money on any level of the budget system for financial provision of legislative and executive powers functions.

2. When we speak about budget expenditures it is reasonable to define "successfulness" as correlation between expenditures and results and effectiveness as profit from the results of activities. Indicators of successfulness reflect correspondence between the results and targets or changing of the result during the definite period.

3. The analysis showed that the budget reform in Russia is far from completion. The existing practice of budget process organization substantially limits possibilities and institutional stimulus of increase of successfulness of state (municipal) finance management and reorientation of administrators' of budget means from use of allocations to achievement of socially significant results which can be measured.

4. Studying the increase of successfulness of budget spending includes the analysis of their planning. Practical implementation of budgeting oriented towards results asks for such tools of planning culture budget spending as registers of spending obligations, departmental targeted programmes, justifications of budget allocations, state and municipal tasks.

5. The analysis of financing the cultural sphere in Samara Region showed that the problems in cultural sphere accumulated during the economic recession of the recent years are much bigger then the state possibilities to solve them: 
- wear rate of the most valuable immovable objects of cultural heritage are higher than the rate of their restoration. The situation with museum funds is the same. As a matter of fact today we face the loss of national heritage (material and spiritual);

- $\quad$ there is the deficit of qualified personnel - young specialists, qualified managers, skilled workers;

- taking into consideration insufficient financing of the cultural sphere, budget allocations can result in progressive dynamics of indicators only after a few years. There is a necessity to provide their stability, allocating resources on solving priority tasks.

6. We suggested taking the following measures to solve the problems revealed:

1) Introduction of the mechanism of public-private partnership. It is the measure which promotes elimination of infrastructural limits of financing cultural institutions, creating optimal conditions for investing in longterm projects, increasing external and internal investments in the sphere of culture.

Public-private partnership is the most important and most universal mechanism of investment policy, contributing to the consolidation of the financial, organizational and management capacities of the private and public sectors of the economy in priority areas. The mechanism of public-private partnership brings together the financial resources of the state, municipalities and businesses that have the means to invest. For cultural institutions, as a result of the reorganization received the status of budgetary institution with an expanded scope of rights, the use of the mechanism of public-private partnership is a tool to obtain additional funds in order to achieve and improve performance.

2) Using methods of estimation of successfulness and effectiveness.

Evaluation of the results of financing the budget institutions is one of the essential components of the budget Evaluation of the results of financing the budget institutions - one of the essential components of the budget planning. Evaluation implies a one-time process monitoring of the quality of work performed by the chief administrator of the budget, in order to increase its effectiveness.

Building a system of performance estimation, which allows to identify the most effective programmes and activities, most popular services or services having the greatest social impact, in our opinion, will largely contribute to the effectiveness of planning expenditures on culture.

Activities of cultural organizations combine the performance of functionally distinct components: the creation of cultural goods, storage, distribution and organization of use of these goods by consumers. In our opinion, for each category of cultural institutions should be worked out the order of planning and financing costs.

7. We have developed a method for assessing the effectiveness of spending on culture in the form of indicators, on the basis of which budget spending can be monitored and evaluated. The system of indicators includes four blocks, reflecting the successfulness of the activities of cultural institutions.

The proposed method allows to determine the state of cultural institutions in the context of financial and sociocultural activities, as well as in comparison with other identical institutions, that will, in our opinion increase the effectiveness and efficiency of budget spending management.

To estimate the effectiveness of institutions of cultural sphere we propose a method for calculating the integral (total) index of budgetary expenditure on culture. Our method allows you to adjust system parameters, to include or exclude additional indicators which are not currently used. Our mechanism of estimation of the effectiveness of spending on culture, on the basis of the system of criteria for financing expenditures, in our view, contributes to optimal planning and financing expenditures, as takes into account the specificity of institutions of culture, their diversity and wide range of their activities.

\section{Acknowledgments}

The authors thank all participants of this study for their kind cooperation.

\section{References}

Afonso, A., Schuknecht, L., Tanzi, V. (2005). Public sector efficiency: an international comparison. Public Choice, 123 (3-4), pp. 321ff.

Afonso, A., M. St., Aubyn, (2006). Cross-country efficiency of secondary education provision: A semi-parametric analysis with nondiscretionary inputs. Economic Modelling, Vol.23, No.3, pp. 476-491.

Babich, A.M., Pavlova, L.N. (1999). State and Municipal Finance. Moscow: UNITY, p.687.

Drobozina, L.A. (2001). Finance. Moscow: UNITY.

Drobozina, L.A., Constantinova, U.N., Okuneva,L.P. (2000). General Theory of Finance, Banks and Stock exchanges. Moscow: UNITY. 
Farrell, J. (1957). The Measurement of productive efficiency. Journal of the Royal Statistical Society, Part III Vol.120, pp. 253-290.

Federal Targeted Programme "Russian Culture (2012 - 2018 )" http://base.garant.ru/70149760/

Gruber, J. (2013). Public Finance and Public Policy. New York: Worth Publishers.

Herrera, S., Pang, G. (2005). Efficiency of public spending in developing countries: An efficiency frontier approach. World Bank Policy Research Working Paper, pp. 36-45.

Kazak, A.U. (2012). Budget Politics and the Quality of Life of the Population of Russia (regional level: problems and decisions). Moscow: Print-Terra-Design.

Khan, M., \& Jain, P. (2010). Management accounting: Text, problems and cases (5th ed.). New Delhi: Tata McGraw Hill Education Private.

Mandl, U., \& Dierx, A. (2008). The effectiveness and efficiency of public spending. Brussels: European Commission, Directorate-General for Economic and Financial Affairs.

Myslyaeva, I.N. (2012). State and Municipal Finance. Moscow: InfraM.

Paramasivan, C., \& Subramanian, T. (2009). Financial management. New Delhi: New Age International (P).

Patil, M. (2013). What is Public Expenditure? Meaning, Definition. KALYAN CITY LIFE

Polyak, G.B. (2012). Finance. Moscow: UNITY-DANA.

Rodionova, V.M. (2002). Finance. Moscow: Finance and Statistics.

Romanovskiy, M.V., Vrublevskaya, O.V., Sabanti, B.M. (2006). Finance. Moscow: Yurite.

Sokolova, O.V. (2000). Finance, Money, Credit. Yurist.

Tkachuk, M.I. (1995). State Budget. Moscow: Yurite.

Vrublevskaya, O.V., Romanovskiy, M.V. (2008). Budget System of the Russian Federation. St. Petersburg: Piter.

Webster, I. (1983). Webster's ninth new collegiate dictionary. Springfield, Mass.: Merriam-Webster. 